\title{
EVALUASI POLITIK HUKUM PENYELENGGARAAN PILKADA LANGSUNG DI PAPUA
}

\author{
Nandang Alamsah Deliarnoor \\ Fakulta Ilmu Politik dan Ilmu Sosial Universitas Padjadjaran Bandung \\ nandangalamsah@yahoo.com
}

\begin{abstract}
Abstrak Apabila politik hukum penyelenggaraan pemilihan umum kepala daerah langsung dievaluasi berdasarkan substansi hukum, struktur hukum dan budaya hukumnya di Provinsi Papua terdapat kelemahan-kelemahan disamping kekuatan-kekuatannya. Dalam substansi hukum terdapat salah interpretasi terhadap makna Pasal dalam konstitusi selain ditemukan kekosongan substansi hukum yang lainnya. Dalam struktur hukum terdapat fenomena banyaknya penyelenggara pemilu yang tersangkut perkara hukum. Dalam budaya hukum terjadi kemerosotan moral yang disebarkan kepada masyarakat (dulu di lembaga perwakilan) dan seolah "politik uang" merupakan sesuatu yang biasa dan tidak bisa dihindarkan, padahal merupakan perbuatan yang bertentangan dengan norma hukum maupun norma sosial lainnya.
\end{abstract}

Kata Kunci : Politik Hukum, Substansi Hukum, Struktur Hukum, dan Budaya Hukum.

\section{EVALUATION OF THE LEGAL POLICY OF DIRECT ELECTIONS IN PAPUA}

Abstract If legal policy of regional heads election were to be directly evaluated based on the legal substance, legal structure and legal culture, the implementation in Papua had some weaknesses despite its strength. In relation to legal substance, there was some misinterpretation of the Article in the Constitution as well as the absence of other legal substance. In legal structure, there was a phenomenon where many participants of the election had been involved in legal cases. In the legal culture, moral decadency, which first occurred in representative institutions, was spreading amongst the society and money politic has become so common it is now perceived as unavoidable, although it is an act that goes against law and other social norms.

Keyword : legal policy, legal substance, legal structure, and legal culture

\section{PENDAHULUAN}

Pada saat tulisan ini dibuat pada awal bulan September 2014 sedang ramai wacana terhadap Rancangan UndangUndang Pemilihan Kepala Daerah (Pilkada) yang sedang dibahas di DPRRI. Materi muatan yang ramai dibicarakan adalah masalah pelaksanaan pilkada yang tadinya dilaksanakan secara langsung dipilih oleh rakyat akan dikembalikan seperti semula yaitu dipilih oleh DPRD atau melalui sistem perwakilan.Pilkada langsung selama ini merupakan produk politik hukum pemerintahan Negara Kesatuan Republik Indonesia pasca reformasi yang bersumber dari Undang-Undang No. 32 Tahun 2004 Tentang Pemerintahan Daerah serta pemaknaan sempit (restriktif) Pasal 18 ayat (4) UUD 1945. Hal ini senada dengan pernyataan Saldi Isra (2012) :

"Meskipun konstitusi hanya menyebut dipilih secara demokratis, pembentuk UU menyejajarkan tata cara pengisian kepala daerah dengan pemilihan presiden. Karena itu, makna "dipilih secara demokratis" dipersempit jadi dipilih secara langsung. Sebagai sebuah legal policy, Pasal 56 UU No. 32 Tahun 2004 menyatakan bahwa kepala daerah dipilih secara demokratis berdasarkan asas langsung, umum, bebas, rahasia, jujur, dan adil. Karena mempersempit makna "dipilih secara demokratis" menjadi "dipilih langsung" diterima sebagai legal policy..." 1

Menurut Hartono Hadisoeprapto (1982 :8), politik hukum adalah suatu kebijaksanaan atau disebut dengan bahasa asing policy dari Penguasa Negara Republik Indonesia mengenai hukum yang berlaku di Negara Indonesia. Politik hukum menurut

\footnotetext{
1. Namun, disinyalir dalam pelaksanaan model Pilkada langsung yang merupakan politik hukum yang dipilih ini memiliki dampak lebih buruk dari pelaksanaan model pilkada melalui sistem perwakilan yang merupakan politik hukum yang dipilih sebelumnya. Hal ini terlihat dari maraknya politik uang yang lebih meluas, bentrok massa, dan lain-lain. ini terlihat dari maraknya politik uang yang lebih meluas, bentrok massa, dan lain-lain.
Dampak lebih buruk pilkada langsung terjadi di tanah Papua yang harus ditebus dengan darah dan nyawa.
}

Teuku Muhammad Radhie (1973 : 4), adalah suatu pernyataan kehendak penguasa negara mengenai hukum yang berlaku diwilayahnya, dan mengenai arah ke mana hukum itu hendak diperkembangkan. Sedangkan politik hukum menurut Moh. Mahfud MD (1993 : 74) adalah kebijaksanaan hukum (legal policy) yang hendak atau telah dilaksanakan secara Nasional oleh Pemerintah Indonesia, yang dalam implementasinya meliputi:

a. Pembangunan Hukum yang berintikan pembuktian hukum dan pembaruan terhadap bahan-bahan hukum yang dianggap asing atau tidak sesuai dengan kebutuhan dengan penciptaan hukum yang diperlukan.

b. Pelaksanaan ketentuan hukum yang telah ada, termasuk penegasan fungsi lembaga dan pembinaan para anggota penegak hukum.

Selanjutnya Satjipto Rahardjo (1986 : 334-335), menyatakan beberapa pertanyaan yang timbul dalam studi politik Hukum adalah :

1. Tujuan apakah yang hendak dicapai dengan sistem hukum yang ada? Tujuan ini bisa berupa satu tujuan besar yang tunggal, bisa juga dipecah-pecah kedalam tujuan-tujuan yang lebih spesifik menurut bidang, seperti ekonomi, sosial, yang kemudian masih bisa dipecah-pecah ke dalam tujuan-tujuan yang lebih kecil lagi.

2. Cara-cara apakah dan manakah yang paling baik untuk bisa dipakai mencapai tujuan tersebut? Termasuk di dalamnya persoalan pemilihan antara hukum tertulis atau tidak tertulis, antara sentralisasi dan desentralisasi.

3. Kapankah waktunya hukum itu perlu diubah dan melalui cara-cara bagaimana perubahan itu sebaiknya dilakukan? 
4. Dapatkah dirumuskan suatu pola yang mapan yang bisa memutuskan kita dalam proses pemilihan tujuan serta cara-cara untuk mencapai tujuan tersebut? Termasuk didalamnya proses untuk memperbaharui hukum secara efisien, dengan perubahan total? Dengan perubahan bagian demi bagian?

Dengan demikian seharusnya (das sollen) suatu politik hukum sejalan antara substansi hukum, struktur hukum dan budaya hukumnya. Namun, politik hukum pilkada langsung untuk Papua menurut penulis ada masalah yang serius menyangkut ketiga hal di atas. Oleh karena itu pertanyaan penelitian yang muncul adalah apakah politik hukum pilkada langsung itu untuk konteks di Provinsi Papua sudah tepat? Berdasarkan pemberitaan maupun hasil observasi langsung penulis di Jayapura dari tanggal 11 Pebruari 2013 sampai dengan 15 Pebruari 2013 bersamaan dengan peristiwa pilkada langsung Gubernur /Wakil Gubernur Provinsi Papua periode 2013-2017, dijumpai permasalahan sebagai dampak pilkada langsung yang tidak baik. Menurut Gubernur Papua Lukas Enembe, saat bertemu Wakil Ketua DPR RI Priyo Budi Santoso awal bulan Mei 2013, di DPR RI Gubernur mengatakan, pemilihan kepala daerah di Papua telah banyak menelan korban jiwa. Korban yang jatuh dalam pilkada bahkan lebih banyak ketimbang akibat gerakan-gerakan separatis. Untuk itu Gubernur Papua meminta pemerintah segera merevisi mekanisme penyelenggaraan Pilkada di Papua (Kompasiana, 4 Juni 2013).

Sebelumnya Haritsah Burhan menjelaskan dalam Kompasiana, 25 Februari 2012 sebagai berikut:

"Kerusuhan karena pemilihan kepala daerah (pilkada) di Provinsi Papua kembali terulang. Sebelumnya kerusuhan terjadi di Kabupaten Puncak Jaya pada 30 Juli 2011 yang mengakibatkan terbakarnya mobil dan rumah dinas bupati serta menewaskan 23 orang. Kerusuhan ini dipicu oleh dua pasang calon bupati Puncak Jaya yaitu Elvis Tabuni dan Simon Alam yang mengaku didukung oleh partai yang sama saat mendaftar di KPUD setempat. Selanjutnya kerusuhan terjadi di Kabupaten Lany Jaya pada 10 September 2011 yang mengakibatkan terbakarnya perumahan Dinas Pertanian \& Kehutanan serta SMP Negeri 4 Tiom. Kerusuhan ini disulut oleh keputusan Mahkamah Konstitusi yang menolak gugutan salah satu pasangan yaitu Briur Wenda-Solayen Tabuni, dimana pasangan tersebut telah memenangkan pemilihan di tingkat distrik namun dirubah oleh KPUD setempat.Kemudian kerusuhan terjadi di Kabupaten Tolikara. Kerusuhan yang bermula pada 14 Februari 2012 itu melibatkan dua kubu pendukung calon bupati yaitu kubu John Tabo dan kubu Usman Wanimbo serta disebabkan tidak diakuinya panitia pemilihan daerah oleh kubu John Tabo. Kerusuhan tersebut mengakibatkan sejumlah kerugian materi yaitu terbakarnya 121 rumah, 1 unit mobil, dan 2 unit motor. Juga dibakarnya kantor Panitia Pemilihan Distrik, Biro Pusat Statistik, Partai Demokrat, dan Partai Golkar. Sedangkan kerugian non-materi dari kerusuan tersebut adalah 201 orang yang menjadi korban luka berat dan ringan serta tewasnya 11 orang. Menurut Haritsah tiga kerusuhan karena pemilihan kepala daerah yang menewaskan puluhan orang dalam kurun waktu tujuh bulan bukan hal yang biasa. Banyaknya kerusuhan yang terjadi membuat kita merasa apakah sistem pemilihan kepada daerah secara langsung layak dilaksanakan di Papua".

Berdasarkan data di atas penulis akan mencoba mengevaluasi politik hukum sistem pilkada langsung ini dengan meneliti praktek penyelenggaraannya di Provinsi Papua berdasarkan legal substance, legal structure dan legal culture (Lawrence M. Friedman, 2009). Menurut Friedman (2009 : 17) suatu sistem hukum dalam operasi aktualnya merupakan sebuah organisme kompleks di mana struktur, substansi, dan kultur berinteraksi.

\section{METODE}

Metode penelitian yang digunakan adalah metode yuridis normatif dengan pendekatan kualitatif dan dikaji secara holistik. Holistik digunakan karena peraturanperaturan yang ada maupun yang akan dibuat harus dikaji titik tautnya dengan peraturan dan aspek-aspek yang lain, terutama untuk melihat apakah kelemahan dan kekuatan peraturan yang ada ketika diimplementasikan pada kondisi nyata khususnya di Provinsi Papua.

Metode yuridis normatif disebut juga dengan pendekatan yuridis-normatif, artinya pengkajiannya didasarkan pada falsafah hukum, asas-asas hukum dan norma-norma hukum yang berlaku. Soerjono Soekanto dan Sri Mamudji (1995 :14), menyebut pendekatan ini dengan istilah metode penelitian hukum normatif yang mencakup penelitian terhadap asasasas hukum, penelitian terhadap sistematik hukum, penelitian terhadap sinkronisasi vertikal dan horisontal, perbandingan hukum dan sejarah hukum. Dijelaskan pula bahwa penelitian hukum normatif itu ialah penelitian hukum yang dilakukan dengan cara meneliti

\section{bahan pustaka atau data sekunder belaka.}

Bagir Manan (1999: 9) yang menyebut pendekatan ini dengan istilah metode penelitian normatif saja yaitu penelitian terhadap kaidah dan asas hukum (hukum positif). Bagir Manan juga membagi dua penelitian hukum yaitu penelitian hukum murni dan terapan. Penelitian ini termasuk penelitian hukum terapan terutama mengenai penelitian evaluasi hukum. Bagir Manan menyebutkan bahwa evaluasi hukum itu bisa karena ada hukumnya tetapi tidak memadai lagi, karena kurang tepat cara-cara pengaturannya, atau memang belum ada aturannya. (Manan, 1999 : 6).

Secara garis besar pendekatan ini bisa diilustrasikan berangkat dari kajian norma-norma, kemudian menukik ke masyarakat (objek penelitian/ masalah) dan kembali nanti hasilnya norma. Jadi secara singkat dirumuskan dengan :

$$
\begin{aligned}
& \mathbf{N}-\mathbf{-}=\text { Norma } \\
& \mathbf{M}=\text { Masyarakat }
\end{aligned}
$$

Selain itu pendekatan yang digunakan adalah penelitian kualitatif dengan metode penulisan secara deskriptif. Adapun yang dimaksud dengan penelitian kualitatif menurut Moleong (2006 : 6) adalah:

"Penelitian Kualitatif adalah penelitian yang dimaksudkan untuk memahami fenomena tentang apa yang dialami oleh subyek penelitian misalnya perilaku, persepsi, motivasi, tindakan, dll secara holistic dan 
dengan cara deskripsi dalam bentuk kata-kata dan bahasa, pada suatu konteks khusus yang alamiah dan dengan memanfaatkan berbagai metode ilmiah".

Moleong berpendapat bahwa penelitian kualitatif berlatar ilmiah sebagai keutuhan mengandalkan analisis manusia sebagai alat (instrumen) penelitian. Mengandalkan analisis data secara induktif mengarahkan sasaran penelitian pada upaya menemukan teori dasar, bersifat deskriptif, lebih mementingkan proses daripada hasil. Penelitian deskriptif menurut Moleong adalah: "data yang dikumpulkan berupa data-kata, gambar, dan bukan angka-angka. Hal ini disebabkan oleh adanya penerapan metode kualitatif.Selain itu, semua yang dikumpulkan berkemungkinan menjadi kunci terhadap apa yang sudah diteliti”. (Moleong, 2006: 11).

Dalam penelitian ini teknik pengumpulan data dilakukan dengan studi pustaka dan studi lapangan. Studi pustaka (library research) dilakukan di Kantor Biro Hukum Pemerintahan Daerah Provinsi Papua, KPU Provinsi Papua, MRP, DPRP, Panitia Pengawas Pemilu Provinsi Papua dan Perpustakaan Universitas Cendrawasih di Jayapura untuk mendapatkan buku, referensi, dokumen-dokumen, laporan, kliping, peraturan perundang-undangan khususnya perdasus dan perdasi, dan Putusan Mahkamah Konstitusi. Studi lapangan (field research) dilaksanakan mulai tanggal 11 Februari 2013 sampai dengan 15 Februari 2013 di Kota Jayapura dan sekitarnya bersamaan dengan proses penetapan pemenang pemilihan Gubernur/Wakil Gubernur provinsi Papua 2013-2017 yang dimenangkan oleh Lukas Enembe. Informannya adalah aktor-aktor dari supra dan infra struktur politik di tanah Papua seperti Majelis Rakyat Papua, Dewan Perwakilan Rakyat Papua, Komisi Pemilihan Umum Provinsi Papua, Panitia Pengawas Pemilu Provinsi Papua, Rektor Universitas Cendrawasih, Pemerintah Daerah Provinsi, Unsur Masyarakat, Mahasiswa, Aktivis, dan Para Tokoh Masyarakat Papua (Para Calon Gubernur/Wakil Gubernur).

\begin{tabular}{|c|c|c|}
\hline No & Supra Struktur Politik & Infra Struktur \\
\hline 1. & $\begin{array}{l}\text { Wakil Ketua I MRP, Drs. Hofni } \\
\text { Simbiak besertapara anggota MRP } \\
\text { yang lainnya. }\end{array}$ & $\begin{array}{l}\text { Drs. Wellington Wenda, M.Si, Tokoh } \\
\text { Masyarakat, Calon Gubernur 2013-2017, } \\
\text { beliau juga waktu itu menjabat Bupati } \\
\text { Kabupaten Pegunungan Bintang. }\end{array}$ \\
\hline 2. & $\begin{array}{l}\text { M. Ferry Kareth, S.H., M.Hum., } \\
\text { Komisioner KPU Provinsi Papua. }\end{array}$ & $\begin{array}{l}\text { Dr. Alex Hasegem, Calon Gubernur } \\
\text { 2013-2017 yang diusung } 16 \text { Partai, } \\
\text { Mantan Wakil Gubernur Papua. }\end{array}$ \\
\hline 3. & $\begin{array}{l}\text { Onny J.J. Lebelauw, S.E., Ketua } \\
\text { Panwaslu Provinsi Papua. }\end{array}$ & $\begin{array}{l}\text { Weynand B. Watory, Calon Wakil } \\
\text { Gubernur 2013-2017 unsur } \\
\text { perseorangan. }\end{array}$ \\
\hline 4. & $\begin{array}{l}\text { Julius, Inna, Natali, dan Harun, Para } \\
\text { Anggota Dewan Perwakilan Rakyat } \\
\text { Daerah Papua dari Komisi A. }\end{array}$ & $\begin{array}{l}\text { Drs. Festus Simbiak, M.Si, Rektor } \\
\text { Universitas Cendrawasih saat itu. }\end{array}$ \\
\hline & $\begin{array}{l}\text { Rosina Upessy, S.H., Kepala Biro } \\
\text { Hukum Pemerintah Provinsi Papua. }\end{array}$ & $\begin{array}{l}\text { Dua mahasiswa Universitas Cendrawasih } \\
\text { dan seorang aktivis pemuda di Kota } \\
\text { Jayapura. }\end{array}$ \\
\hline
\end{tabular}

Pemilihan lokasi penelitian di Provinsi Papua didasarkan pada keunikan daerah ini sehingga ada politik hukum tersendiri dari NKRI dengan menempatkan tanah Papua sebagai daerah otonomi khusus yang didasarkan pada keragaman kebudayaan, sejarah, adat istiadat, dan bahasa sendiri (Konsideran huruf e UU No. 21 Tahun 2001 tentang Otonomi Khusus Bagi Provinsi Papua).

\section{HASIL DAN PEMBAHASAN}

\section{A. Evaluasi Substansi Hukum Pilkada Langsung Di Papua.}

Menurut Lawrence M. Friedman (2009 : 16), Substansi hukum (legal substansce), berkenaan dengan peraturan-peraturan dan ketentuan mengenai bagaimana institusi-institusi itu harus berperilaku. Oleh karena itu pada bagian ini penulis akan melakukan evaluasi terhadap politik hukum yang berkaitan dengan norma atau kaidah yang mengatur pilkada langsung di Papua.

Memaknai isi suatu norma dalam peraturan perundang-undangan merupakan tindakan mengadili yang dapat berakibat fatal bila salah dalam melakukan tindakan mengadili itu. Ungkapan lebih baik melepaskan 10 orang yang bersalah daripada menghukum satu orang yang tidak bersalah, mengandung arti pula bahwa walau manfaat yang didapatkan hanya sedikit namun jangan sampai diabaikan dalam tindakan mengadili itu.

Demikian pula ketika Pasal 18 ayat (4) UUD 1945 khususnya kata-kata "dipilih secara demokratis" dimaknai oleh pengambil kebijakan yang mengeluarkan UU No. 32 Tahun 2004 untuk dipilih secara langsung oleh rakyat maka sebagaimana layaknya "vonis" yang merasakan akibatnya adalah orang-orang yang terkena vonis tersebut. Penulis berpendapat bahwa kata-kata dipilih secara demokratis harus dihubungkan dengan cita hukum berdemokrasi bangsa Indonesia itu sendiri seperti yang tertuang dalam Pancasila. Butir 4 Pancasila mengamanatkan bahwa kerakyatan yang dipimpin oleh hikmat kebijaksanaan dalam permusyawaratan/perwakilan. Hal ini mengandung makna bahwa dalam berdemokrasi harus diutamakan "hikmat kebijaksanaan", dan untuk kasus ini dalam berdemokrasi di tanah Papua (pilkada) alangkah bijaksananya bilamana yang dipilih adalah bentukbentuk musyawarah atau melalui sistem perwakilan. Hal ini dikarenakan tingkat pendidikan politik di tanah Papua masih sangat rendah dibanding saudarasaudaranya di bagian Indonesia yang lainnya.

Rektor Universitas Cendrawasih Drs.Festus simbiak, M.Pd yang berhasil ditemui penulis pada hari selasa, 12 Februari 2013 di Jayapura, menyatakan bahwa :

a. Demokrasi harus bijak jangan melihat Indonesia dengan kacamata Jawa.

b. Penduduk asli Papua $60-70 \%$ ada di luar kota.

c. Kepemimpinan ondafi atau kepala suku yang turun-temurun atau kepemimpinan mambri (jago) seperti di Biak mempengaruhi konsep demokrasi di tanah Papua.

d. Perlu dimunculkan alternatif sistem pemilihan seperti model keterwakilan yang dimodifikasi seperti calon dari partai tertentu juga mencalonkan calon lain dari luar partainya.

Wakil Ketua I Majelis Rakyat Papua (MRP) Drs. Hofni Simbiak, menemukan perbedaan yang tidak rasional antara jumlah penduduk dan Daftar Pemilih Tetap (DPT). Bilamana menemukan kasus seperti ini ternyata dari sisi materi hukum belum ada yang mengaturnya, apakah yang dipegang adalah 
data kependudukan atau DPT yang dikeluarkan oleh KPU. Masalah DPT ini disampaikan pula oleh calon Gubernur Papua periode 2013-2017, Bapak Welington Wenda yang didampingi calon wakil gubernurnya yaitu Bapak Weynand B. Watori kepada penulis. Menurutnya ada kekacauan dalam teknik pelaksanaan penentuan DPT yang tidak bagus (rasional), jumlah penduduk 2,9 juta lalu jumlah DPTnya hanya 2,7juta dan yang mendapatkan undangan 2,1juta dan 600 ribu, hal tersebut dianggap tidak rasional.

Welington menceritakan pengalamannya sebagai seorang calon Gubernur bahwa kelemahan pilkada langsung di daerah papua ini banyak sekali kendala, yang pertama yaitu kondisi daerah Papua, yang harus melakukan kampanye ke 29 titik, kondisi daerah yang sukar untuk di tempuh karena jauhnya tempat dan cuaca tidak menentu sehingga transportasi sangat mahal dan hanya 2 titik saja yang bisa di lalui oleh jalan darat atau mobil selebihnya harus menggunakan jalur udara sehingga susah untuk dilakukan dan biayanya sangat mahal. Untuk menyewa sebuah pesawat carteran dibutuhkan biayan sekitar Rp.80 juta, sehingga dari 29 titik itu hanya 6 titik saja yang terkunjungi, dengan kondisi daerah yang berat itu para calon gubernur hanya diberi waktu masa kampanye 12 hari saja menurut ketentuan peraturan perundang-undangan, sehingga timbullah masalah kedua yaitu mahalnya biaya kampanye.

Berdasarkan fakta di atas maka penulis juga melihat adanya norma hukum yang tidak memperlakukan secara adil khususnya untuk masa kampanye di Provinsi Papua yang tidak memperhitungkan kondisi geografis dan sarana prasarana yang dimiliki daerah tersebut. Norma hukum tentang masa kampanye di Papua ini sebaiknya ditambah bukan hanya 12 hari seperti yang diberlakukan di daerah lain. Demikian pula jangka waktu minggu tenang sebelum masuk pelaksanaan pilkada yang dapat dibedakan pengaturan waktunya dengan daerah lain. Akibat medan yang sulit di bumi Papua ada juga kejadian berdasarkan berita republika.co.id selasa, 12 Februari 2013 pelaksanaan pilkada tertunda karena kapal motor yang membawa logistik pilkada terbakar. Kapal motor "Fajar lintas irja" jenis landing ship tank (LST) yang membawa logistik pilkada untuk dua wilayah (TPS) di Kabupaten Supiori, senin jam 08.00 WIT terbakar hingga menyebabkan logistik belum dapat dilaksanakan, akibatnya penduduk di pulau Mapia dan pulau Meosbefondi pencoblosan ditunda, 119 surat suara untuk pulau Mapia dan 346 untuk pulau Meosbefondi.

Substansi hukum tentang Pilkada langsung yang merupakan produk politik hukum NKRI ini mendapat kritikan sangat pedas dari para anggota DPRP. Salah seorang anggota DPRP yaitu Ibu Inna yang mencurigai bahwa politik hukum pilkada langsung yang diberlakukan di tanah Papua itu memang suatu kesengajaan agar masyarakat asli Papua saling jotos, saling bunuh sehingga penduduk aslinya akan musnah, sehingga orang-orang dari luar penduduk asli akan dengan leluasa untuk menguasai tanah Papua yang kaya raya.
DPRP sebenarnya sudah menjalankan tugasnya menyusun substansi hukum berupa Perdasus bersama Gubernur seperti yang diamanatkan UU No. 21 Tahun 2001 Tentang Otsus, yaitu Peraturan Daerah Khusus Provinsi Papua Nomor 6 Tahun 2011 Tentang Pemilihan Umum Gubernur dan Wakil Gubernur dan ditetapkan tanggal 28 Desember 2011. Namun Perdasus ini belum tuntas dilaksanakan berhubung adanya gugatan sengketa kewenangan yang diajukan KPU ke Mahkamah Konstitusi. Pada tanggal 19 september 2012 keluar Putusan MK Nomor 3/ SKLN-X/2012 yang intinya mengabulan gugatan KPU untuk menyelenggarakan pilkada langsung di Papua sebagaimana halnya terjadi di daerah lain di Indonesia. Dengan demikian sempat terjadi kekosongan substansi hukum yang menjadi pijakan untuk melaksanakan pilkada langsung khususnya Pilkada Gubernur dan Wakil Gubernur di Provinsi Papua itu. Oleh karena itu seperti disampaikan Ferry Kareth salah seorang Komisioner KPU Provinsi Papua yang dapat penulis jumpai di Jayapura, pihak KPU Provinsi Papua menjadi serta merta menyiapkan substansi hukum untuk melaksanakan pilkada langsung Gubernur dan Wakil Gubernur pada tahun 2013 tersebut.

Namun, pendapat berbeda terlontar dari dua mahasiswa dan seorang aktivis pemuda di Jayapura yang memiliki pandangan berbeda dengan para tokoh masyarakat Papua tentang substansi hukum pilkada di tanah Papua. Menurut mereka pengaturan pilkada yang dilaksanakan secara langsung itu sudah baik konsepnya karena lebih mencerminkan demokrasi. Mereka menjadi lebih merasa berperan dalam partisipasi memilih wakilnya baik di lembaga perwakilan maupun memilih kepala daerahnya. Penulis memahami bahwa pemikiran anak-anak muda ini penuh dengan idealisme yang kadangkadang mengalahkan realita apa yang sesungguhnya terjadi dalam praktek.

Menarik untuk disampaikan dalam masalah substansi hukum Pilkada Langsung di Papua ini adalah penerapan "sistem noken". Menurut Neles Tebay (2014) noken adalah tas anyaman tradisional Papua yang dibuat dari kayu dan digunakan orang Papua yang mendiami pegunungan. Noken tidak didatangkan dari luar karena dibuat oleh penduduk lokal, terutama kaum wanitanya. Noken yang merupakan warisan budaya ini digunakan dalam pemilu -baik pilkada, pemilu legislatif, maupun pilpres entah sebagai sarana pengganti kotak suara, entah sebagai representasi calon atau pasangan calon.

Berdasarkan wawancara dengan Onny Lebelauw. SE, Ketua Panitia Pengawas Pemilihan Umum Propinsi Papua berdasarkan pengamatannya sistem noken memang rawan diselewengkan oknum-oknum, karena penduduk setempat tidak mencoblosnya sehingga dimanfaatkan oleh orang-orang yang tidak bertanggungjawab. Menurut Onny Keputusan KPU tentang sistem noken perlu disempurnakan. Memang diakui juga menurut Feri Karet komisioner KPU Provinsi Papua permasalahan yang bisa menimbulkan konflik adalah sistem noken, karena tidak langsung, bebas dan rahasia. Unsur-unsur asas yang diamanatkan 
oleh Undang-undang No. 32 Tahun 2014 yaitu asas langsung, umum, bebas, rahasia, jujur, dan adil hanya terpenuhi dua asas yaitu jujur dan adil. Menurut pendapat Wakil Ketua I Majelis Rakyat Papua (MRP) Drs. Hofni Simbiak yang mengomentari tentang penerapan sistem noken ini menyatakan bahwa sistem noken atau kantong memang perlu sosialisasi dan dikaji serta di sempurnakan kekurangannya kalau memang akan terus dilakukan sistem Pilkada langsung di tanah Papua.

Calon Gubernur Wellington Wenda menjelaskan pula bahwa sistem noken (sistem kantong) rawan kecurangan dan dipergunakan oleh orang yang membayar kepala suku untuk memaksa warganya, akibatnya ketika ada yang memprotes pelaksanaan noken itu dibunuh beramai-ramai seperti yang terjadi terhadap ketua komisi A DPRD Kabupaten Tolikara dari fraksi partai Golkar. Menurut republika.co.id nama anggota DPRD yang tewas pasca menggunakan hak pilihnya itu adalah Josia Karoba yang tewas di keroyok oleh para kerabatnya sendiri di TPS distrik Gilibandu Kabupaten Tolikara.

Perkembangan UU Pilkada yang mengembalikan pelaksanaan Pilkada dengan sistem perwakilan untuk konteks Papua menjadi tepat karena substansi hukum ini akan saling bersesuaian dengan struktur yang telah ada di Papua yaitu keberadaan DPRP dan MRP. Demikian pula substansi hukum sistem perwakilan ini akan sesuai dengan kultur hukum masyarakat Papua yang secara demografi sangat sulit dijangkau. Kultur hukum masyarakat Papua yang senang bermusyawarah seperti tercermin dalam penggunaan noken semakin memperkuat alasan terhadap penggunaan sistem perwakilan. Namun, UU Pilkada yang mengembalikan pelaksanaan Pilkada dengan sistem perwakilan harus dicabut oleh Peraturan Pengganti Undang-Undang (Perpu) di penghujung berakhirnya masa jabatan presiden SBY periode ke 2 ini.

\section{A. Evaluasi Struktur Hukum Pilkada Langsung Di Papua.}

Struktur hukum (legal structure) menurut Lawrence M. Friedman (2009 : 15-16) adalah kerangka badannya; ia adalah bentuk permanennya, tubuh institusional dari sistem tersebut, tulang-tulang keras yang kaku yang menjaga agar proses mengalir dalam batas-batasnya. Dalam hal proses pilkada yang menjadi struktur hukumnya adalah KPU, Bawaslu/ Panwaslu, dan DKPP. Namun khusus di Papua struktur hukum dalam proses Pilkadanya memiliki struktur khusus yaitu adanya keterlibatan MRP dan DPRP. Dalam konsiderans huruf b Peraturan Daerah Khusus Provinsi Papua Nomor 6 Tahun 2011 tentang Pemilihan Umum Gubernur dan Wakil Gubernur dijelaskan bahwa dalam rangka penyelenggaraan Otonomi Khusus, Pemilihan Umum Gubernur dan Wakil Gubernur di Provinsi Papua dilaksanakan oleh Dewan Perwakilan Rakyat Papua dan Komisi Pemilihan Umum Provinsi dengan memposisikan peran Majelis Rakyat Papua sebagai Lembaga Kultur.

Menarik untuk diungkap permasalahan yang menyangkut struktur dalam penyelenggaraan pilkada di Papua ini adalah perseteruan lembaga KPU dan DPRP. Menurut Pasal 7 ayat 1 Undang-
Undang Nomor 21 Tahun 2001 tentang Otonomi Khusus Papua Dewan Perwakilan Rakyat Papua lah yang berwenang memilih gubernur dan wakil gubernur, sehingga dalam pelaksanaannya di Papua pernah pendaftaran bakal calon gubernur dan wakil gubernur dilakukan oleh Dewan Perwakilan Rakyat Papua. Kemudian KPU Provinsi Papua menggugat ke Mahkamah Konstitusi dan menang tertuang dalam Putusan MK Nomor 3/SKLN-X/2012. Setelah adanya putusan MK tersebut selanjutnya yang melaksanakan pemilihan gubernur adalah KPU dengan sistem pemilihan langsung. Hal ini terungkap dari hasil wawancara dengan pihak MRP yang diwakili Ketua I MRP Drs. Hofni Simbiyak, yang menyatakan bahwa pilkada di Papua secara hukum masih menimbulkan masalah walaupun sudah ada keputusan MK bahwa yang berwenang untuk menyelengarakan pilkada adalah KPU. Namun ketidakpuasan struktur hukum yang yang tidak puas dengan keputusan MK tersebut terus membayangi sampai saat ini.

Berdasarkan fakta di atas menunjukkan bahwa ternyata pengadilan in casu Mahkamah Konstitusi berkontribusi besar dalam pembentukan politik hukum di negeri ini pasca Amandemen UUD 1945. Mahkamah konstitusi menjadi salah satu organ "penguasa negara" yang dapat menciptakan politik hukum. Hal ini sejalan dengan apa yang diungkapkan oleh Teuku Muhammad Radhie (1973 : 4), bahwa politik hukum itu adalah suatu pernyataan kehendak penguasa negara mengenai hukum yang berlaku diwilayahnya, dan mengenai arah ke mana hukum itu hendak diperkembangkan. Ternyata Mahkamah Konstitusi memberikan arah perkembangan hukum terhadap pilkada itu dengan pilkada langsung, untuk diberlakukan di Papua termasuk menetapkan lembaga yang berwenang dalam penyelenggaraannya.

Tidak urung dampak dari adanya politik hukum ini menjadikan molornya pelaksanaan pilkada di Papua. Menurut Ferry Kareth, Komisioner KPU Provinsi Papua, seharusnya pemilihan gubernur dan wakil gubernur Papua periode 2013-2017 itu di laksanakan pada tanggal 26 September 2011, tetapi akibat sengketa kewenangan untuk menentukan penyelenggara pilkada Gubernur/ Wakil Gubernur ini apakah yang berwenang itu DPRP atau KPU, menyebabkan proses pilkada menjadi terhenti. Baru setelah ada keputusan MK tanggal 19 September 2012 yang menyatakan bahwa KPUlah yang berwenang melaksanakan pilkada, maka proses pelaksanaan pilkada dapat dilanjutkan kembali dan hal-hal yang sudah dikerjakan DPRP di serahkan kepada KPU.

Dalam Amar Putusan Keputusan MK Nomor 3/ SKLN-X/2012 memang dinyatakan bahwa Pemohon dalam hal ini KPU Provinsi Papua berwenang melaksanakan semua tahapan Pemilihan Umum Gubernur dan Wakil Gubernur di Papua, termasuk meminta kepada Mejelis Rakyat Papua untuk memberikan pertimbangan dan persetujuan terhadap bakal pasangan calon Gubernur dan Wakil Gubernur Papua. Namun dalam Amar Putusan ini juga dinyatakan bahwa semua bakal pasangan calon yang sudah diverifikasi dan ditetapkan Dewan Perwakilan Rakyat Papua berdasarkan kewenangan yang diberikan UU Otsus Papua dinyatakan sah oleh MK. 
Mencermati permasalahan lembaga penyelenggara pemilu oleh KPU atau DPRP di Papua, Onny Lebelauw. SE, sebagai Ketua Panitia Pengawas Pemilihan Umum Propinsi Papua, menyatakan bilamana politik hukum pilkada ke depan akan dilaksanakan kembali melalui sistem perwakilan dan dilaksanakan oleh DPRP menurutnya tidak masalah. Namun syaratnya DPRP mau diawasi oleh Panwaslu sesuai amanat UU No. 15 Tahun 2011. Pengawasan menurut Onny menjadi syarat mutlak agar pelaksanaan pemilu berlaku jujur dan adil.

Namun, dalam rangka melakukan pengawasan tersebut menurut Onny di lapangan terungkap bahwa para pengawas ini kerap mendapat ancaman dari pihak-pihak tertentu. Dengan demikian menurut Onny para aktor yang terlibat dalam struktur hukum pilkada ini termasuk pengawas pemilu perlu mendapatkan perlindungan hukum ekstra. Menurut Onny jangan hanya terhadap saksi dan korban saja yang mendapat perlindungan hukum itu yang selama ini regulasinya memang sudah ada yaitu UU tentang Perlindungan Saksi dan Korban. Namun, perlindungan hukum terhadap para penyelenggara pemilu ini harus dimunculkan dalam UU tersendiri atau menjadi masukkan bagi perbaikan UU No. 15 Tahun 2011 Tentang Penyelenggara Pemilu.

Sebagai perbandingan di daerah lain justru dalam struktur hukum pilkada terdapat fenomena banyaknya penyelenggara pemilu dalam hal ini KPU Daerah yang tersangkut perkara hukum. Berdasarkan data yang penulis dapatkan di Pengadilan Tanjungpinang sedang digelar kasus yang melibatkan Ketua KPU Batam. Demikian pula komisioner KPU Kabupaten Anambas bermasalah dan satu lagi komisioner KPU Kabupaten Karimun tersangkut masalah hukum.

Berkaitan dengan struktur hukum dalam penyelenggaraan pilkada langsung di tanah Papua ada yang membedakan juga dengan pelaksanaan di daerah lain yaitu pelibatan Majelis Rakyat Papua. Berdasarkan wawancara dengan Ferry Kareth komisioner KPU Provinsi Papua, ciri khas pilkada gubernur dan wakil gubernur di Papua adalah perlibatan Majelis Rakyat Papua didalam rangkaian pilkada yaitu untuk menyeleksi apakah bakal calon benar-benar penduduk asli Papua atau bukan.

Berdasarkan uraian di atas setidaknya dapat tergambar bahwa dari sisi struktur hukum dalam penyelenggaraan pilkada langsung di Provinsi Papua ini ditemukan masalah sengketa kewenangan lembaga, yang walaupun sudah ada Putusan MK Nomor 3/ SKLN-X/2012 namun berdasarkan pengamatan penulis di lapangan ketidakpuasan dari pihak DPRP masih tergambar karena mereka merasa lebih berhak berdasarkan UU Otsus Papua dan sisi kemanfaatan pilkada sistem perwakilan lebih baik dari pada pilkada langsung dimana kondisi daerah dan sosial Provinsi Papua yang yang tidak mendukung dan berbeda dengan daerah lainnya di Indonesia.

\section{B. Evaluasi Budaya Hukum Pilkada Langsung di Papua.}

Menurut Lawrence M. Friedman (2009 : 17) budaya hukum (legal culture) berkenaan dengan elemen sikap dan nilai sosial. Dalam masalah budaya hukum pelaksanaan pilkada di Papua telah terjadi kemerosotan moral yang disebarkan kepada masyarakat (dulu di lembaga perwakilan) dan seolah "politik uang" merupakan sesuatu yang biasa dan tidak bisa dihindarkan, padahal merupakan perbuatan yang bertentangan dengan agama maupun peraturan perundang-undangan.

Menurut pendapat Wakil Ketua I Majelis Rakyat Papua (MRP) Drs. Hofni Simbiak bila demokrasi modern tidak di jembatani dengan kearifan lokal maka akan menimbulkan konflik. Mengukur budaya orang lain dengan budaya sendiri akan bisa menimbulkan masalah. Suatu kenyataan Pilkada langsung di Papua ini menjadikan maraknya money politic dan tentu akan berimbas pada soal moral. Martabat manusia bahkan nyawa digadaikan dengan uang atau benda. Sudah berapa banyak nyawa melayang akibat uang dalam proses pilkada langsung ini. MRP sebagai penjaga keragaman kebudayaan, sejarah, dan adat istiadat Papua tidak rela rakyat Papua menjadi terdegradasi moralnya bahkan saling bunuh akibat bentrokan langsung dalam proses pilkada langsung. Beliau lebih setuju untuk tanah Papua pilkada dilaksanakan sengan sistem perwakilan sesuai amanat otonomi khusus untuk Papua.

Menurut Welington tentang money politic atau politik uang maka setiap satu kecamatan katanya diberi uang kisaran Rp.100 juta dan desa Rp.25 juta. Bahkan saat kampanye ada calon yang melempar uang dari atas panggung senilai Rp.100 juta sehingga warga berebutan dan terinjak-injak sehingga memakan korban dua orang tewas dalam kampanye tersebut (penulis membayangkan seperti seorang peternak membagikan makanan saja). Tidak kurang warga Papua yang apatis sehingga mereka memilih golput (golongan putih). Akhirnya saran untuk pemilihan gubernur dari Welington Wenda ini adalah sebaiknya diangkat saja oleh presiden seperti pengangkatan pejabat eselon dua.

Pengalaman Welington di atas dibenarkan pula oleh Dr. Alex Hasegem yang ikut mencalonkan diri sebagai calon gubernur periode 2013-2017 juga. Dr. Alex Hasegem pernah menjadi wakil gubernur Papua sehingga beliau dapat merasakan perbedaan bagaimana sulitnya pelaksanaan pilkada langsung sekarang ini untuk konteks Papua dibandingkan dengan sistem sebelumnya yaitu sistem perwakilan. Beliau juga berpendapat kebijakan pilkada langsung untuk konteks Papua adalah tidak tepat.

Menurut Haritsah Burhan (2012) Papua termasuk daerah tertinggal seperti data Kementerian Negara Pembangunan Daerah Tertinggal yang menyebutkan bila 27 dari 183 kabupaten tertinggal di Indonesia berada di Papua. Umumnya daerah tertinggal memiliki kualitas sumberdaya manusia yang rendah, yang dicirikan oleh indeks pembangunan manusia (IPM), yaitu rendahnya rata-rata lama sekolah (RLS), angka melek huruf (AMH), dan angka harapan hidup (AHH). Kualitas pendidikan di Papua juga rendah. Faktanya ketertinggalan SD di Papua mencapai 12 tahun dibanding daerah lainnya di tanah air. Sedangkan SMP di Papua ketertinggalannya 15 tahun. Angka kemiskinan di Papua juga sangat tinggi bahkan termasuk terbesar di Indonesia. Tahun 2007 penduduk miskin Papua berjumlah lebih dari 974.000 orang. Tahun selanjutya berjumlah lebih 934.000 orang. Tahun 2009 naik hingga lebih 997.000 
orang. Tahun 2010 meningkat menjadi lebih dari 1.031 .000 orang dan September 2011 berjumlah lebih 917.000 orang. Melihat fakta jumlah kekerasan dan ketertinggalan di atas, sudah selayaknya pelaksanaan pilkada untuk Papua ditinjau ulang oleh pemerintah pusat. Sistem pilkada secara langsung belum aman diterapkan di daerah yang rawan konflik. Hal ini bertujuan untuk mengurangi resiko terjadinya kerusuhan yang menyebabkan kerugian harta benda bahkan jiwa raga.

Berdasarkan pemberitaan Tribunnews.com, tanggal 9 September 2014 Tokoh masyarakat, akademisi dan politisi Papua meminta Pilkada tidak langsung diterapkan di Papua.Mereka mendatangi DPRRI yang sedang menggodok RUU Pilkada dan Revisi RUU Otsus Papua. Pertimbangannya adalah situasi di Papua kalau Pilkada langsung terlalu banyak konflik sampai-sampai merusak tatanan adat dan keluarga di Papua. Di Papua banyak yang mati karena Pilkada langsung. Kemudian rentan dengan perang suku, ongkosnya terlalu mahal, penyelenggaraan pemerintah juga menjadi tidak baik dan berimbas pada kerukunan hidup beragama. Di Papua gereja bisa pecah karena urusan Pilkada. Menurut para tokoh ini pemilihan tidak langsung juga konstitusional.

Pernyataan para tokoh Papua ini memperkuat hasil penelitian penulis tentang penyelenggaraan Pilkada langsung di Papua pada tahun 2013 bahwa berdasarkan substansi, struktur dan budaya hukum penyelenggaraan Pilkada langsung di Papua lebih banyak mudaratnya daripada manfaatnya. Oleh karena itu sesuai dengan pernyataan Satjipto Rahardjo (1986 : 334-335), bahwa politik hukum berkaitan dengan kapankah waktunya hukum itu perlu dirubah dan melalui caracara bagaimana perubahan itu sebaiknya dilakukan. Dengan demikian saat ini merupakan saat yang tepat untuk membuat politik hukum yang memberi manfaat pada masyarakat Papua.

\section{SIMPULAN}

1. Sistem noken yang merupakan ciri khas dalam proses pelaksanaan pilkada di Papua belum mendapatkan legalisasi dari Peraturan Perundangundangan. Dengan demikian sistem noken memerlukan pengaturan khusus minimal dalam Perdasus, syukur-sukur terakomodasi sebagai salah satu materi muatan dalam Undang-Undang Tentang Pilkada.

2. Berdasarkan struktur hukum pilkada langsung di Papua memiliki keunikan tersendiri dengan adanya pelibatan lembaga Majelis Rakyat Papua yang memiliki kewenangan untuk menyeleksi keaslian para bakal calon apakah penduduk asli Papua atau bukan.

3. Budaya hukum di Papua untuk saat ini belum cocok untuk pemilihan langsung hal ini terlihat dari maraknya politik uang yang lebih meluas dan bentrok massa yang menunjukkan rendahnya kesadaran hukum masyarakatnya.

\section{Saran.}

1. Dalam hal substansi hukum harus dibuat politik hukum pilkada khusus yang sesuai untuk tanah Papua dengan berlandaskan pada Pancasila yaitu permusyawaratan/perwakilan, sehingga UU
Pilkada yang dibuat dapat menampung kondisi khusus Papua seperti mengakomodasi sistem noken.

2. Dalam hal struktur hukum urgensi dan eksistensi DPRP dan MRP sekarang ini perlu mendapat penguatan dalam Undang-Undang Pilkada sebagai penyelenggara pengisian pejabat publik di tanah Papua.

3. Perlu proses percepatan penyejahteraan dan pendidikan politik bagi masyarakat di Papua yang akan menjadi sarana penting agar kultur hukum dalam proses demokrasi meningkat.

\section{DAFTAR PUSTAKA}

Burhan, Haritsah, Evaluasi Sistem Pilkada Di Papua, Kompasiana, 25 Februari 2012.

Friedman, Lawrence M. 2009. Sistem Hukum, Perspektif Ilmu Sosial, diterjemahkan dari Buku The Legal System: A Social Science Perspective, New York: Russell Sage Foundation, 1975, oleh M. Khozim, diterbitkan oleh Penerbit Nusa Media, Ujungberung Bandung.

Hadisoeprapto, Hartono, 1982. Pengantar Tata Hukum Indonesia, Yogyakarta : Liberty.

Isra, Saldi, Kontroversi Putaran Kedua Pilkada, Kompas Kamis, 19 Juli 2012.

Mahpud, Moch. MD. 1993. Perkembangan Politik Hukum Studi Tentang Pengaruh Konfigurasi Politik Terhadap Produk Hukum Di Indonesia, Yogyakarta : Disertasi UGM.

Manan, Bagir.1999. Penelitian Di Bidang Hukum, artikel dalam Jurnal Hukum Puslitbangkum Lembaga Penelitian Universitas Padjadjaran Nomor Perdana : 1-1999.

Moleong, 2006, Metodologi Penelitian Kualitatif, Bandung : PT Remaja Rosdakarya.

Radhie,Teuku Mohammad, dalam PRISMA No. 6 Th. Ke II, Desember 1973.

Rahardjo, Satjipto, 1966, Ilmu Hukum. Bandung : Alumni.

Soekanto, Soerjono dan Sri Mamudji, 1995, Penelitian Hukum Normatif, Jakarta : Raja Grafindo Persada.

Tebay, Neles, Sistem Noken dan Demokrasi, Kompas, Kamis 21 Agustus 2014.

Sumber lain :

Kompasiana, 4 Juni 2013.

Republika.co.id

Tribunnews.com, 9-9-2014.

UUD 1945.

UU No. 21 Tahun 2001 tentang Otonomi Khusus Bagi Provinsi Papua.

UU No. 32 Tahun 2004 Tentang Pemerintahan Daerah.

Peraturan Daerah Khusus Provinsi Papua Nomor 6 Tahun 2011 Tentang Pemilihan Umum Gubernur dan Wakil Gubernur.

Putusan Mahkamah Konstitusi Nomor 3/SKLN-X/2012. 